\title{
Ultra-Lightweight Cement Slurry to Seal Wellbore of Poor Wellbore Stability
}

\author{
Marcin Kremieniewski $(0)$ \\ Oil and Gas Institute-National Research Institute, 25A Lubicz Str., 31-503 Krakow, Poland; \\ marcin.kremieniewski@inig.pl
}

Received: 8 May 2020; Accepted: 11 June 2020; Published: 16 June 2020

\begin{abstract}
The article presents the recipe for ultra-lightweight cement slurry for wellbore sealing. In ordinary lightweight cement slurries, the addition of microspheres and a large amount of water are used to maintain rheological parameters. This is a problem because the light particles of microspheres segregate. The cement sheath from such a cement slurry has an anisotropic microstructure and does not stabilize the casing column. In the new ultra-light cement slurry, $60 \%$ aluminosilicate microspheres and a large amount of water were used. The ultra-light weight slurry has a density below $1.2 \mathrm{~g} / \mathrm{cm}^{3}$. This cement slurry does not segregates and in the sedimentation stability test has the same density at all measuring points. The cement slurry, despite the larger amount of water, has the same filtration as the control sample. The technological parameters of the slurry are adapted to the borehole conditions. Cement slurry is a ready-made application to seal a borehole with poor wellbore stability under conditions of $40^{\circ} \mathrm{C}$ and $10 \mathrm{MPa}$ pressure. The cement sheath structure in the wellbore after binding is homogeneous. The use of such slurry allows to reduce the risk of wall damage in wellbores of poor stability.
\end{abstract}

Keywords: cement slurry; lightweight cement slurry; ultra-lightweight cement slurry; segregation; sedimentation stability; wellbore stability; concrete; perlite

\section{Introduction}

Lightweight cement slurry should be used to seal casing columns in absorbent zones and in reservoirs of low reservoir pressure. The density of such slurry falls within a conventional range from approx. 1400 to $1750 \mathrm{~kg} / \mathrm{m}^{3}$ [1-4]. The application of such cement slurry allows to reduce the hydrostatic pressure in the wellbore, reducing possibility of cement penetration into absorbent zones [5-10]. However, geological conditions happen to exist in a wellbore, which force to apply ultra-lightweight cement slurry. Such slurry density is lower than $1200 \mathrm{~kg} / \mathrm{m}^{3}$ [11-13].

Drilling in structures of poor wellbore stability is one of most problematic tasks. This is related to wellbore zones friability due to tectonic disturbances and harmful action of the drilling fluid on the rock. Lightweight cement slurry is used to seal casing columns under such geological conditions [14-21]. It contains fillers of density lower than the cement density. Microspheres are most frequently used at designing recipes of lower density slurry [22-24]. This is a filler containing spherical elements from 400 to $600 \mathrm{~kg} / \mathrm{m}^{3}$ density, to the interior of which filled with gas. The introduction of microspheres to the cement slurry results in significant reduction of its density, which is presented in Figure 1 [3]. 


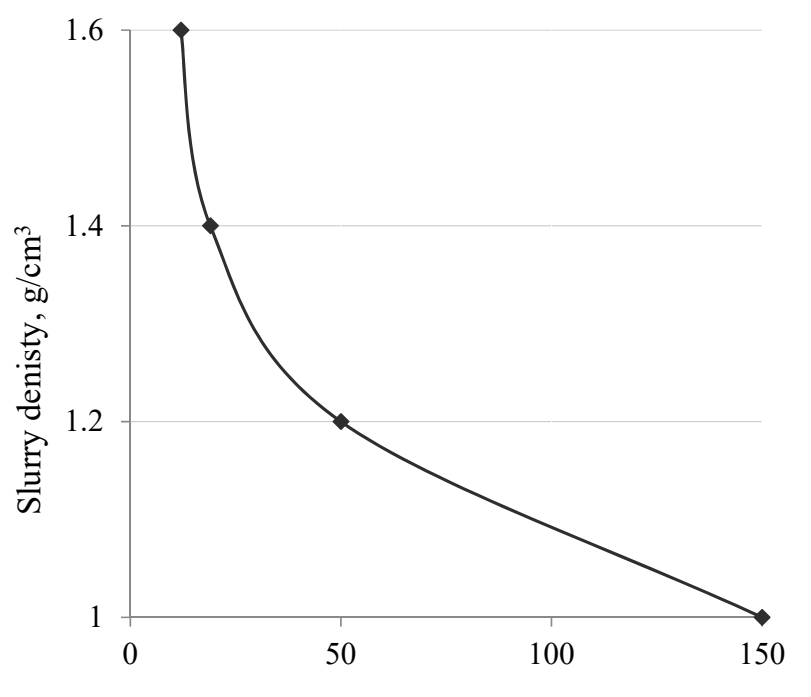

Aluminosilicate microspheres, \% BWOC

Figure 1. Slurry density versus microspheres content. \% BWOC is \% share of the microspheres content against the cement mass.

When analyzing the slurry density dependence on microspheres content it is possible to notice a possibility to reduce the slurry density to approx. $1100 \mathrm{~kg} / \mathrm{m}^{3}$. Such density may be obtained at $100 \%$ microspheres content against the cement mass (BWOC-by weight of cement) [3,25]. However, the use of such high amounts of lightweight filler results in strong segregation of the slurry. Already from a content of $40 \%$ (BWOC) of microspheres the sedimentation stability may be lost. Such slurry is not capable of maintaining mutual arrangement of cement particles in an unchanged form under the effect of acting external forces [26-30]. In such a case, lightweight fractions present in the slurry hang in the upper part of the sealed ring space. A layer of mixing water separated from the slurry is situated in the central part [31]. While, heavy fractions fall to the lower parts of the wellbore ring space. Figure 2 presents a visualization of such an effect.

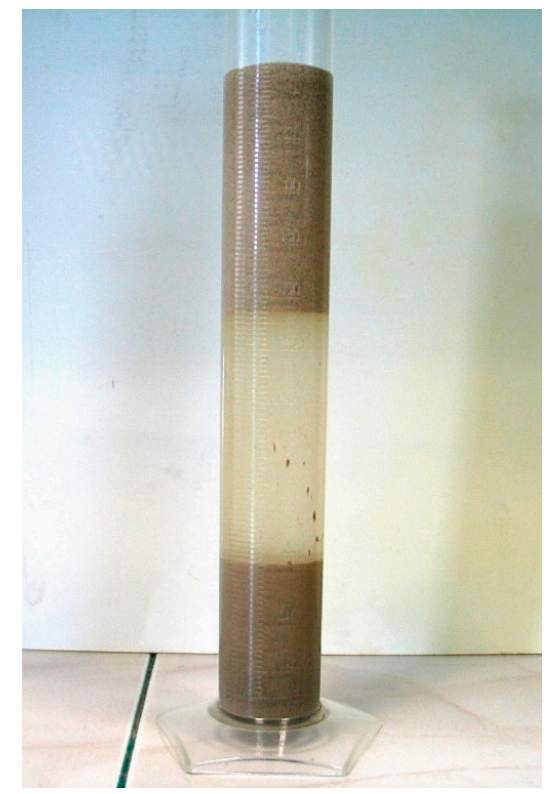

Figure 2. An example of overly segregating cement slurry containing a significant amount of microspheres.

It is significant that appropriate stability of the cement slurry is the main factor of effective sealing of casing column. Numerous adverse effects may occur in the case of using slurry showing excessive 
segregation. Poorly designed cement slurry shows propensity for stratification (Figure 2) and for excessive separation of free water, which is invisible in the upper part. A part of this water is absorbed by the rock formation [32-40]. This can result in e.g., clogging of the wellbore zone, local weakening of the cement sheath after its binding, or excessive occurrence of spaces enabling the gas flow [41-45]. Poor cementing or even the lack of cementing ultimately occurs, which is visible after performance of Cement Bond Log (CBL) measurements $[19,38]$. The elimination of cement slurry components segregation is affected by the water-cement ratio and the amount of used lightweight filler. To obtain appropriate sedimentation stability it is necessary to reduce the amount of used filler, however, such an action results in an undesired increase in the slurry density. Additionally, fine-grained fillers are used, which cause an increase in the disperse system viscosity [46-52]. The above factors result in severe limitations on ultra-lightweight cement slurry designing.

The information about slurry of reducing density is available in the sector literature $[6-8,10,17,19$, $21,25,28,33,42,48]$. Additionally, the data on building mortar of concrete materials or mixes designed for the use in construction industry is available. Instead, the information about ultra-lightweight cement slurry intended for application mainly in wellbore mining is missing. Due to this, the author presents in this paper results of own studies on development on a new recipe of ultra-lightweight cement slurry. The author found that the application of ultra-lightweight cement slurry does not disturb the wellbore stability. This is important from the energy economy point of view. The use of high-density slurry may induce hydraulic fracturing and loss of slurry, hence, ineffective cementing operation.

\section{Materials and Methods}

\subsection{Materials}

CEM I 42.5R Portland cement was used to make the slurries. The cement contains $2.66 \% \mathrm{SO}_{3}$ and $0.065 \% \mathrm{Cl}^{-}$. Slurry conditioning agents were added. PSP 046 cement plasticizer was delivered by Polski Serwis Płynów Wiertniczych. Sp. z o.o. Poland. It is a liquefying agent based on modified lignosulphonates and naphthalene with a bulk density of $0.44 \pm 0.11 \mathrm{~g} / \mathrm{cm}^{3}$ and a pH from 6.6 to 8.5 . The content of $\mathrm{Cl}^{-}$is below $0.1 \%$, while that of $\mathrm{Na}_{2} \mathrm{O}$ does not exceed $1.5 \%$. In order to eliminate aeration, a defoamer was used, which is a mixture of unsaturated fatty acid esters and refined hydrocarbons. The product was supplied by Polski Serwis Płynów Wiertniczych. Sp. z o.o. Poland. The slurry contained an antifiltrating agent and setting accelerator. The products were supplied by Polski Serwis Płynów Wiertniczych. Sp. z o.o. Poland. To eliminate gas microflows, latex was used, which is a water dispersion of styrene butadiene copolymer and latex stabilizer. The latex was supplied by Polski Serwis Płynów Wiertniczych. Sp. z o.o. Poland. The inter-grain space was sealed with a 10\% addition of micro-cement supplied by Halliburton Micro Matrix. This product contains grains of less than or equal to $10 \mu \mathrm{m}$ and a surface area approx. $1400 \mathrm{~m}^{2} / \mathrm{kg}$. Furthermore, bentonite was used to increase the viscosity of the mixing water, so that the microspheres used to reduce the slurry density did not segregate. Bentonite was supplied by Certech Poska.

Loose silica dust (amorphous silica) was used to improve the mechanical performance of the cement sheath made of the slurry. Specific surface area: $18,000 \mathrm{~m}^{2} / \mathrm{kg}(\mathrm{BET})$, average grain size: approx. $0.15 \mu \mathrm{m}$. The silica dust was supplied by Huta Łaziska, Poland. Cenospheres, purchased from Cenospheres Trade \& Engineering S.A., were used to reduce density. This is an additive in the form of spherical aluminosilicate microspheres, $200-500 \mu \mathrm{m}$ in diameter. They are filled with gas, mainly carbon dioxide and nitrogen. Their density is $0.8 \mathrm{~g} / \mathrm{cm}^{3}$, and the bulk density is less than $0.4 \mathrm{~g} / \mathrm{cm}^{3}$. They feature a high $\mathrm{SiO}_{2}$ and $\mathrm{Fe}_{2} \mathrm{O}_{3}$ content and a low $\mathrm{Al}_{2} \mathrm{O}_{3}$ content. Additionally, filtration perlite EP 100F was used, purchased from PERLIPOL Polska company. This is an admixture of very high absorbability, reaching a value of as much as $500 \%$. The bulk density is $50-120 \mathrm{~kg} / \mathrm{m}^{3}, \mathrm{pH} 6.5-7.5$. The $\mathrm{SiO}_{2}$ content is $70 \%$, and that of $\mathrm{Al}_{2} \mathrm{O}_{3}$ is $15 \%$.

The percentage of additives is summarized in Table 1. 
Table 1. Selected compositions of cement slurries cured at the temperature of $40{ }^{\circ} \mathrm{C}$ and under the pressure of $10 \mathrm{MPa}$.

\begin{tabular}{|c|c|c|c|c|}
\hline Composition & Action & 1 & 2 & 3 \\
\hline Water-cement ratio & & 0.98 & 0.90 & 1.10 \\
\hline Plasticizer & Cement slurry liquefies & 0.2 & 0.3 & 0.4 \\
\hline Latex & $\begin{array}{l}\text { Reduces filtration, counteracts gas migration } \\
\text { through cement sheath }\end{array}$ & - & 10.0 & 5.0 \\
\hline Stabilizer & $\begin{array}{c}\text { Provides good, even, and durable latex } \\
\text { dispersion }\end{array}$ & - & 1.0 & 1.0 \\
\hline Bentonite & Increases viscosity water & 1.5 & 1.5 & 0.75 \\
\hline Defoaming agent & Prevents foam formation & - & 0.5 & - \\
\hline Antifiltrating agent & Reduces cement slurry filtration & 0.5 & 0.4 & 0.4 \\
\hline Setting accelerator & Accelerates cement slurry setting & 2.5 & 3.0 & 4.0 \\
\hline Micro-cement & Seals the matrix of hardened cement slurry & 5.0 & - & 5.0 \\
\hline Cenospheres & Reduces cement slurry density & 15.0 & 40.0 & 60.0 \\
\hline Microsilica & $\begin{array}{l}\text { Seals inter-cement space and has pozzolanic } \\
\text { properties }\end{array}$ & 一- & - & 5.0 \\
\hline Filter perlite & High water absorption, prevents segregation & - & - & 2.5 \\
\hline Cement CEM I 42,5R & It sets the cement slurry & 100.0 & 100.0 & 100.0 \\
\hline
\end{tabular}

All components in $\%$ by mass of cement. Bentonite in $\%$ by weight of water.

\subsection{Slurry Preparation}

Three recipes were prepared to develop ultra-lightweight cement slurry to seal wellbore of poor wellbore stability. The first two slurries are control samples-lightweight cement slurries. Sample No 1 contains $15 \%$ of microspheres, and sample No $240 \%$ of microspheres. The ultra-lightweight cement slurry No 3 contains $60 \%$ of microspheres and due to a high amount of lightweight additive it contains sedimentation stability improvers. To prepare cement slurry, a specific amount of water was measured with a measuring cylinder. Water was poured into a mixer that mixed it at $1600 \mathrm{rpm}$. Bentonite was added to the water, and it was mixed for $30 \mathrm{~min}$. Then the remaining remedies were added to the cement slurry and mixed for $10 \mathrm{~min}$. After this time, loose additives were added and mixed for another $20 \mathrm{~min}$. The low mixing speed corresponds to the preparation of the slurry in the well conditions. Component amounts in individual slurries are specified in Table 1.

\subsection{Experimental Procedures}

The technological properties of fresh and solidified slurries were tested in accordance with the following standards:

- PN-EN ISO 10426-2. Petroleum and natural gas industries. Cements and materials for well cementing. Part 2: Testing of well cements. The tests include the following measurements: slurry density, filtration, thickening time, sedimentation stability, adhesion to steel, and gas permeability.

- PN-EN 196-1: 2006 Methods of testing cement. Determination of Strength. Compressive strength was tested according to this standard.

Slurries were prepared at ambient temperature. The increase in compressive strength and thickening time was studied in conditions similar to those prevailing in the wells: temperature $40^{\circ} \mathrm{C}$, pressure $10 \mathrm{MPa}$.

\subsubsection{Slurry Density}

The cement slurry density was tested with a Baroid mud balance. The scale had a container for cement slurry on one side and calibrated counterweight on the other. The density measurement can be read in the range of $0.8-2.75 \mathrm{~g} / \mathrm{cm}^{3}$. The density was determined from the properly set indicator on the balance arm. 


\subsubsection{Slurry Filtration}

Filtration testing was carried out using a dynamic filter press. The measurement conditions correspond to those prevailing in the wellbore. It is possible to take measurements at up to $232{ }^{\circ} \mathrm{C}$ and pressures up to $14 \mathrm{MPa}$ [53].

\subsubsection{Rheological Properties}

The OFITE model 900 viscometer was used to determine the rheological properties of the cement slurries. Rheological properties were tested by determining shear curves in the velocity range from 1.7 to $1022 \mathrm{~s}^{-1}$. The test was carried out at $20^{\circ} \mathrm{C}$. For determining the rheological the Rheosolution 3.02 software (version 3.02, manufacturer AGH University of Science and Technology, Cracow, Poland) was used, which is the property of the AGH University of Science and Technology Faculty of Drilling, Oil and Gas [54-58]. In addition, a slurry flow curve was drawn.

\subsubsection{Thickening Time}

The pressure consistometer was used to measure cement slurry thickening time. In the device it is possible to measure the start time of thickening and the end time of thickening. The device allows recording the progress of maturing cement slurry and establishing the start of the thickening time, and its end [53].

\subsubsection{Sedimentation Stability of the Slurry}

The sedimentation stability of the slurry was measured by means of a sedimentation column as shown in Figure 3. The column for sedimentation measurements consists of a cylinder divided into three parts. The column houses adjustable valves, which can be used to cut out individual parts with the slurry. To determine the sedimentation stability the slurry was prepared in accordance with the standard [53]. Then the slurry was conditioned in a consistometer to achieve the required temperature. The slurry was placed in the sedimentation column. After $2 \mathrm{~h}$, valves cutting out individual slurry parts were closed. Then the density of slurry from individual column parts (top, central, bottom) was measured by means of a mud balance. The slurry that is not subject to sedimentation has the same density values at all measurement points [53].

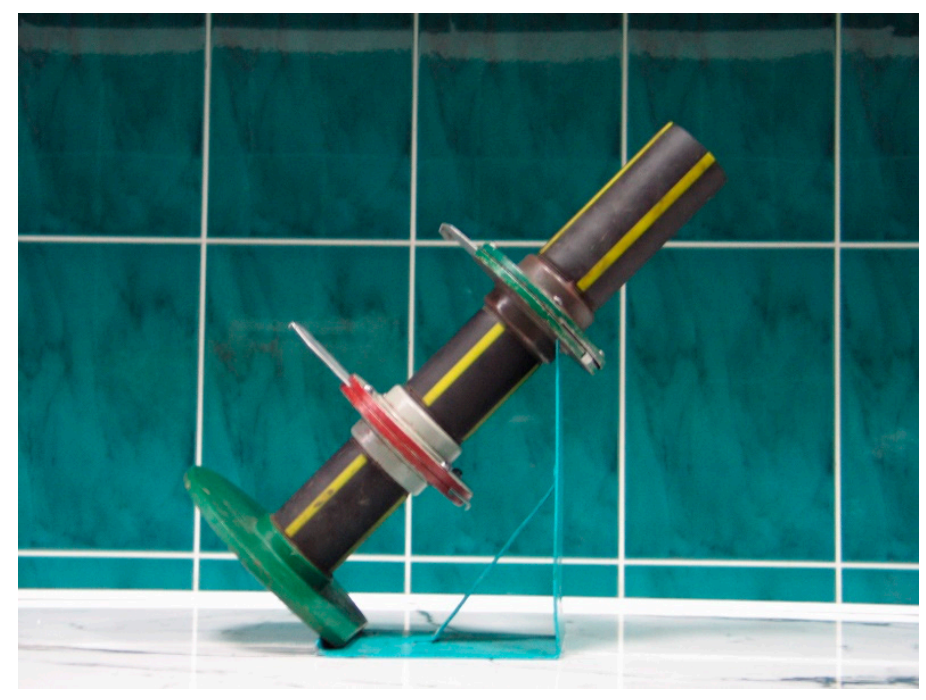

Figure 3. Column for measuring the stability of sedimentation of cement slurry.

\subsubsection{Non-Destructive Compressive Strength Test}

Testing of the increase in compressive strength of cement slurries was carried out by the non-destructive method. The test was carried out using a model 120-51 Twin Cell Ultrasonic Cement 
Analyzer (OFI Testing Equipment, Inc., Houston, TX, USA). The cement slurry sample was placed in the chamber. Then an ultrasonic wave passes through the sample. The value was calculated from the correlation that exists between the ultrasonic wave passage time and the increasing compressive strength. The device allows to measure the compressive strength while the cement slurry is being bound in conditions similar to those of a well. The diagram of the device is shown in Figure 4 [59].

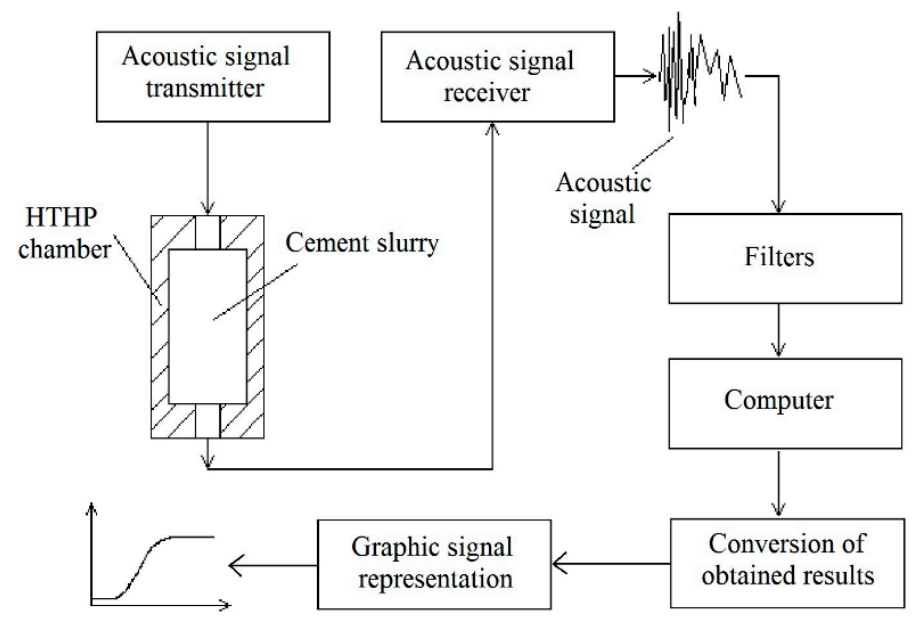

Figure 4. Simplified diagram of the ultrasonic cement analyzer.

\subsubsection{Hardened Cement Slurry Adhesion to Steel Pipes}

The adhesion of hardened cement slurry to steel pipes was measured by means of a testing machine. A measuring set presented in Figure 5 was used for testing. Rings are made of steel with surface roughness of $\mathrm{Rz}=10 \mu \mathrm{m}$ according to PN-EN ISO 1302 [60]. A core was placed concentrically in the ring (Figure 6). The mold was filled with cement slurry and stored in a thermostated tub in tap water under semi-wellbore conditions (temperature and pressure) for a defined period of time. After cement hydration the sample (Figure 7) was placed between two plates of the testing machine (Figure 8). Under the influence of smoothly applied load the force of adhesion breaking between hardened cement slurry and pipe was measured [53]. The adhesion in MPa was calculated according to Equation (1).

$$
\sigma_{\mathrm{p}}=\frac{\mathrm{p}}{\mathrm{s}} \cdot 10^{-3}
$$

where $\mathrm{p}$ is force of pressure causing a break of hardened cement slurry connection with the steel pipe $(\mathrm{kN})$; $\mathrm{s}$ is contact surface of the rock sample with the cement stone $(\mathrm{m})$.

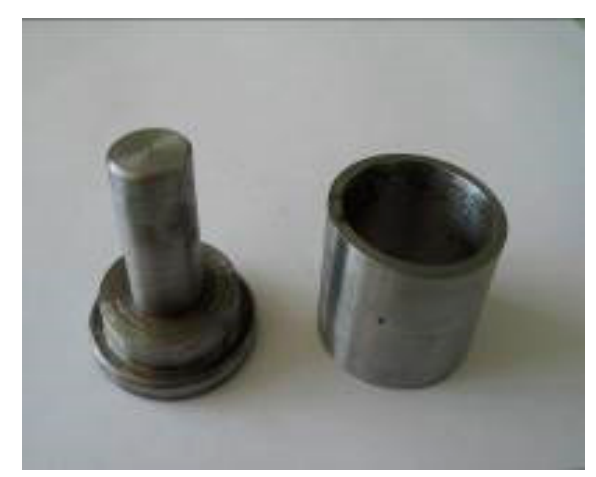

Figure 5. Measuring set used to determine adhesion of hardened cement slurry to the casing pipe. 


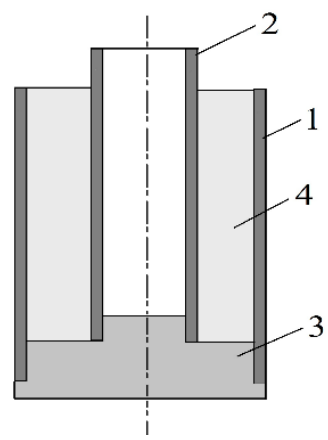

Figure 6. Diagram of a sample to determine cement stone adhesion to steel. 1—external ring; 2 -internal core; 3-'distance' base; 4-hardened cement slurry.

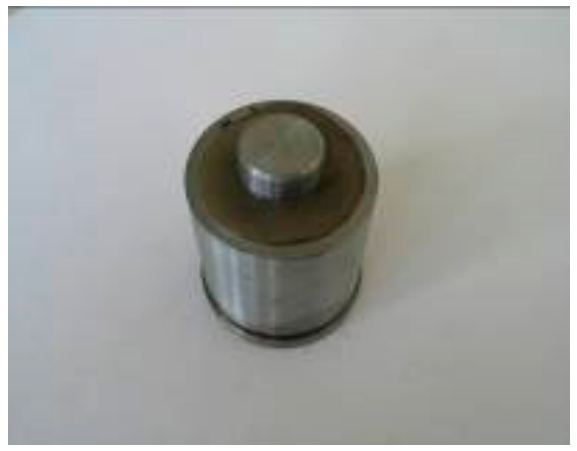

Figure 7. Finished sample to determine adhesion of hardened cement slurry to the casing pipe.

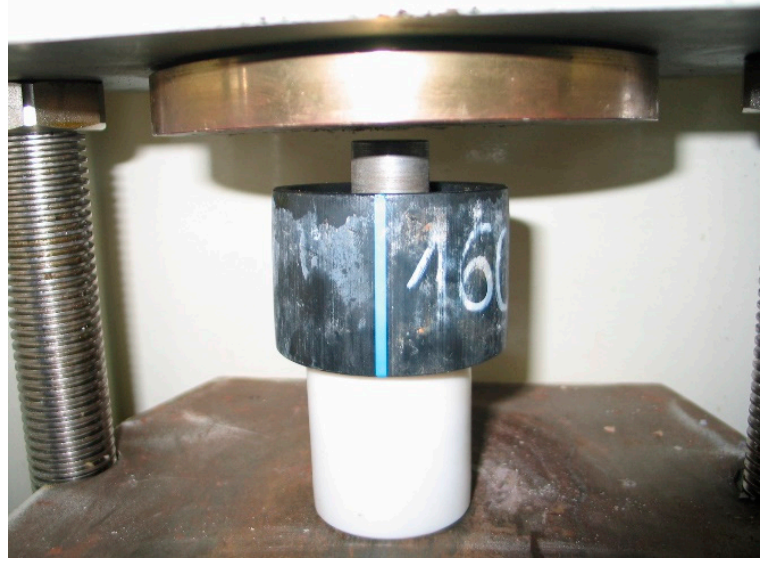

Figure 8. Sample adhesion testing by means of testing machine at the cement stone-steel core contact.

\subsubsection{Gas Permeability}

Relative gas permeability was tested in accordance with the standard [53] by means of a cement permeameter. A sample, one inch long and in diameter, was made of liquid slurry. The sample was placed in a rubber sleeve and then in a cylinder. Nitrogen was introduced to the sample and by means of a calibrated flowmeter the flow rate was measured. The permeability of hardened cement slurry was determined from the Darcy's law (Equation (2)) [53].

$$
K=\frac{2000 \cdot P_{o} \cdot Q \cdot \mu \cdot L}{A \cdot\left(P_{1}^{2}-P_{0}^{2}\right)}
$$

where $K$ is permeability $(\mathrm{mD}) ; P_{o}$ is output pressure (atmospheric pressure) (atm); $P_{1}$ is input pressure (atm); $Q$ is flow rate of the medium (liquid) (cc/sec); $\mu$ is viscosity (cP) (nitrogen viscosity $=0.1756 \mathrm{cP}$ under ambient conditions); $L$ is length of sample $(\mathrm{cm}) ; A$ is area of sample cross-section $\left(\mathrm{cm}^{2}\right)$, 


\subsubsection{Pore Structure}

The porosity was tested by means of a mercury porosimeter. The sample of hardened cement slurry was placed in the penetrometer and then in the porosimeter. The device performs automatic measurements based on measurements of capillary pressure curves. The test was based on the relationship between the amount of capillary pressure and the dimension of radius and its shape and the network of mutual links between pores of diversified radii. Based on the analysis and interpretation of porosimetry test results, mainly the quantities calculated based on capillary pressure curves, a porosity calculated from a porosimeter was obtained.

\subsubsection{Non-Homogeneity of Sample Microstructure}

The non-homogeneity of sample was measured based on the porosity analysis at various measurement points. To this end liquid slurry was poured into a cylinder $1 \mathrm{~m}$ long and $2.5 \mathrm{~cm}$ in diameter. After slurry binding three samples were taken for porosity testing. Porosity was measured in three parts of the cylinder: top, middle, and bottom. The uniformity of hardened cement slurry was determined based on the obtained results. A sample with a big porosity difference at various measurement points confirms the existence of cement sheath non-homogeneity in the wellbore.

\section{Results}

\subsection{Slurry Density}

As Table 2 shows, the lightweight slurries used so far feature densities ranging from 1.22 (slurry no. 2) to $1.44 \mathrm{~g} / \mathrm{cm}^{3}$ (slurry no. 1). While, the newly designed ultra-lightweight slurry has a density of $1.14 \mathrm{~g} / \mathrm{cm}^{3}$ (slurry no. 3). The reference slurry no. 1 has the highest density. This is caused by the smallest amount of aluminosilicate microspheres, which were used at an amount of $15 \%$ (BWOC). It does not contain latex as a component and $5 \%$ of micro-cement addition was applied to seal the cement sheath matrix. As Table 2 shows, the density of the second slurry is $1.22 \mathrm{~g} / \mathrm{cm}^{3}$, which results from the application of $40 \%$ of aluminosilicate microspheres. This slurry does not have a micro-cement addition and the cement sheath matrix was sealed with $10 \%$ addition of latex. The presence of latex allows to reduce the $\mathrm{w} / \mathrm{c}$ ratio (water-cement ratio, expresses the amount of water per unit of cement) as compared with slurry no. 1 (Table 1). The density of newly developed ultra-lightweight slurry is $1.14 \mathrm{~g} / \mathrm{cm}^{3}$. Such a value was obtained by introduction of $60 \%$ of aluminosilicate microspheres. To reduce rheological parameters the slurry has $\mathrm{w} / \mathrm{c}=1.1$. Latex is present in the ultra-lightweight slurry because of a large amount of mixing water, and micro-cement and microsilica for microstructure sealing. The amount of bentonite $(0.75 \%)$ in the slurry is smaller than in previous slurries. A significant amount of microspheres and mixing water in the slurry usually causes segregation. Therefore, the new recipe has fine-grained additives and additionally $2.5 \%$ of filter perlite with high water absorption (Table 1).

Table 2. Properties of cement slurries with additives and admixtures.

\begin{tabular}{|c|c|c|c|c|c|c|c|c|}
\hline \multirow{2}{*}{$\begin{array}{l}\text { Compo-sition } \\
\text { No. }\end{array}$} & \multirow{2}{*}{$w / c$} & \multirow{2}{*}{$\begin{array}{l}\text { Density } \\
\left(\mathrm{g} / \mathrm{cm}^{3}\right)\end{array}$} & \multirow{2}{*}{$\begin{array}{c}\begin{array}{c}\text { Filtration } \\
\left(\mathrm{cm}^{3}\right)\end{array} \\
\text { After } 30 \text { min of Measurement }\end{array}$} & \multicolumn{2}{|c|}{$\begin{array}{l}\text { Thickening Time } \\
\text { (Hours: min) }\end{array}$} & \multicolumn{3}{|c|}{$\begin{array}{c}\text { Sedimentation Stability } \\
\text { Density in the Column Part }\end{array}$} \\
\hline & & & & $30 \mathrm{Bc}$ * & $100 \mathrm{Bc}$ * & $\begin{array}{l}\text { Upper } \\
\text { Part }\end{array}$ & $\begin{array}{l}\text { Middle } \\
\text { Part }\end{array}$ & $\begin{array}{c}\text { Bottom } \\
\text { Part }\end{array}$ \\
\hline 1 & 0.98 & 1.44 & 290.0 & $4: 20$ & 4:50 & 1.42 & 1.44 & 1.46 \\
\hline 2 & 0.90 & 1.22 & 91.0 & 3:00 & 5:18 & 1.15 & 1.21 & 1.30 \\
\hline 3 & 1.10 & 1.14 & 230.0 & $3: 40$ & 4:10 & 1.14 & 1.14 & 1.14 \\
\hline
\end{tabular}

${ }^{*} \mathrm{Bc}$ - the Bearden unit is used when determining the change in consistency of cement slurry during setting.

The thickening time (consistency change) was tested in an HTHP consistometer (temperature $40{ }^{\circ} \mathrm{C}$ and pressure $10 \mathrm{MPa}$ ), dynamic conditions, time to reach temperature, and pressure $20 \mathrm{~min}$ ). 


\subsection{Slurry Filtration}

The filtration tests were carried out at $40{ }^{\circ} \mathrm{C}$ under dynamic conditions. Filtration measurements of slurries were carried out over $30 \mathrm{~min}$. As Table 2 shows, control slurry no. 1 features the highest filtration, equal to $290 \mathrm{~cm}^{3}$. A high filtration value results from a significant amount of mixing water, $\mathrm{w} / \mathrm{c}=0.98$. Slurry no. 2 features filtration equal to $91 \mathrm{~cm}^{3}$. Filtration in this slurry is lower, because the water-cement ratio is smaller, and in addition the slurry has $10 \%$ of latex, which causes clogging of pore spaces in the network of hydrating cement. The ultra-lightweight slurry no. 3 features filtration equal to $230 \mathrm{~cm}^{3}$. This is a great value, resulting from high $\mathrm{w} / \mathrm{c}=1.1$. However, the ultra-lightweight slurry filtration is much smaller than in lightweight slurry no. 1, which contains less water (Table 1). The introduction of fine-grained materials causes the filtration reduction by $60 \mathrm{~cm}^{3}$ as compared with slurry no. 1.

\subsection{Rheological Properties}

As Table 3 shows, the tested lightweight slurries belong to Newtonian fluids, which are described by the Casson and Herschel-Bulkley models. The lightweight slurry marked no. 1 features the lowest value of flow limit Css $_{0.84} \mathrm{~Pa}$. The coefficient of this slurry consistency HB is $0.041 \mathrm{~Pa} \cdot \mathrm{s}^{\mathrm{n}}$, and the apparent viscosity is $55.99 \mathrm{mPa} \cdot \mathrm{s}$. As Figure 9 shows, the flow curve for this slurry features the lowest course. Low values of analyzed rheological parameters are caused by a high amount of water in the slurry and the smallest amount of microspheres (Table 1). Higher values of rheological parameters in slurry no. 2 (Table 1) result from the addition of $40 \%$ of microspheres and a smaller amount of water. Figure 9 shows the highest course of the flow curve for slurry no. 2. The flow limit css in this slurry increased nearly five times as compared with lightweight slurry no. 1. The coefficient of this slurry consistency $\mathrm{HB}$ is $0.25 \mathrm{~Pa} \cdot \mathrm{s}^{\mathrm{n}}$, while its apparent density has a value of $120 \mathrm{mPa} \cdot \mathrm{s}$ (Table 3). The newly developed ultra-lightweight slurry no. 3 features the greatest amount of water, but contains also significant amounts of fine-grained materials. In addition, this slurry has $2.5 \%$ of filter perlite with high water absorption. Such modifications cause an increase in rheological parameters as compared to standard lightweight slurries no. 1 and 2. As Table 3 shows, the flow limit Css of slurry no. 3 is 4.28 Pa and the coefficient of consistency HB is $0.44 \mathrm{~Pa} \cdot \mathrm{s}^{\mathrm{n}}$. The apparent viscosity of this slurry is much lower than that of slurry no. 1 and is $102 \mathrm{mPa} \cdot \mathrm{s}$. A higher yield stress is indispensable for the ultra-lightweight slurry. This is confirmed in the literature $[61,62]$ where it was found that the low value of yield stress makes it difficult to propose a stable suspension to prevent the segregation of the aggregates. The obtained yield stress value allows to maintain a large amount of microspheres in the drilling fluid. Due to that, the slurry is not subject to segregation, however, it is necessary to consider that and to adapt the pumping pressure to this type of slurry.

Table 3. Rheological properties of cement slurries with additives and admixtures.

\begin{tabular}{ccccc}
\hline \multirow{2}{*}{ Rheological Properties } & $\begin{array}{c}\text { Temperature of } \\
\text { Measurement }\left({ }^{\circ} \mathbf{C}\right)\end{array}$ & \multicolumn{3}{c}{ Composition of Cement Slurry } \\
\cline { 3 - 5 } & 22 & 0.8433 & 3.9339 & $\mathbf{3}$ \\
\hline Yield stress value $\mathrm{Css}(\mathrm{Pa})$ & 22 & 0.0414 & 0.2496 & 0.4360 \\
\hline Consistency index $\mathrm{HB}\left(\mathrm{Pa} \cdot \mathrm{s}^{\mathrm{n}}\right)$ & 22 & 1.0376 & 0.8851 & 0.7832 \\
\hline Flow index $\mathrm{HB}[\mathrm{n}](-)$ & 22 & 55.9978 & 119.9953 & 101.9960 \\
\hline $\begin{array}{l}\text { Apparent viscosity } \\
\text { at 1022 }{ }^{\mathrm{s}-1}(\mathrm{mPa} \cdot \mathrm{s})\end{array}$ & & & & \\
\hline $\begin{array}{l}\text { Css - value described by the Casson's rheological model. } \\
\text { rheological model. }\end{array}$ & $\mathrm{HB}$-value described by the Herschel-Bulkley
\end{tabular}




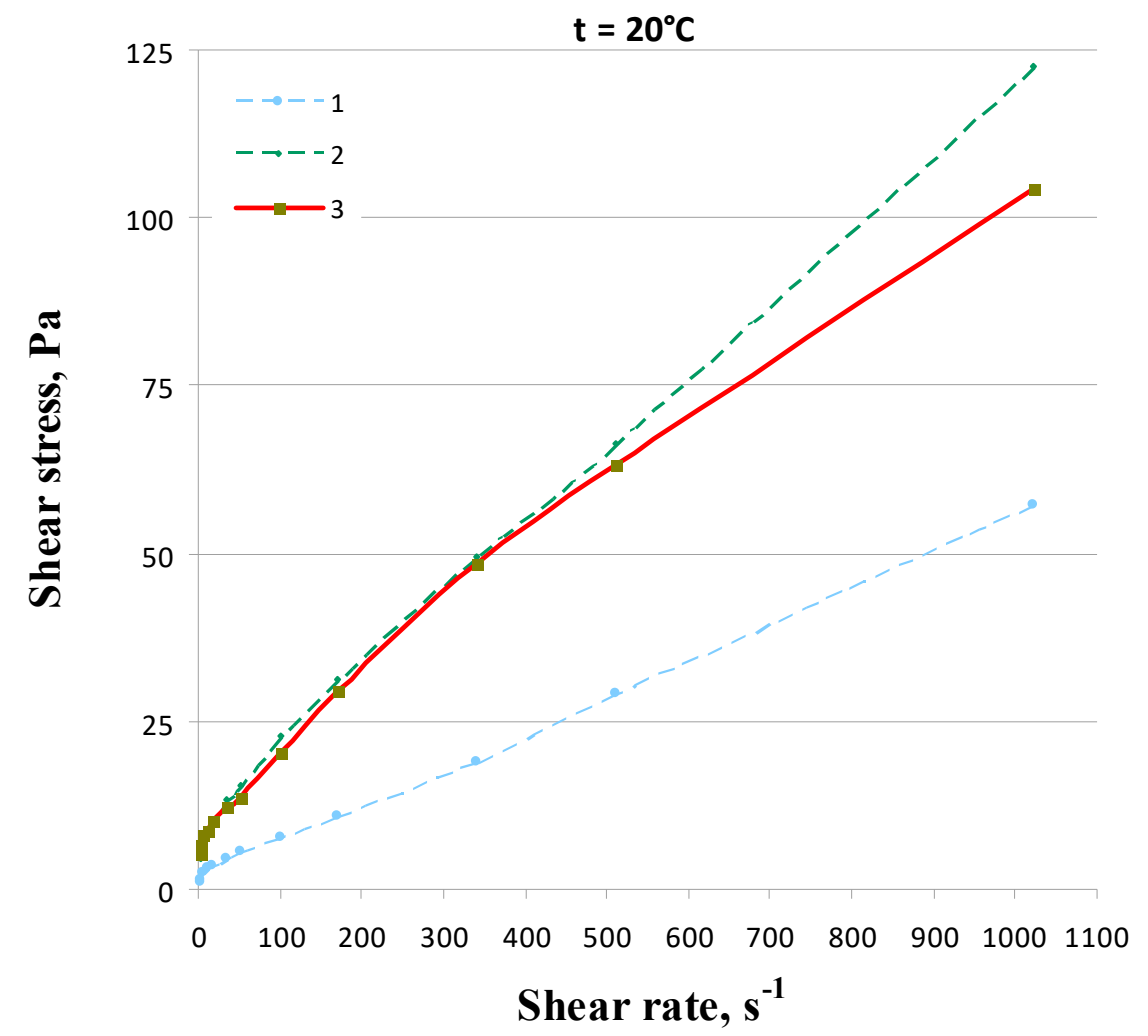

Figure 9. Flow curves of cement slurries at the temperature of $20^{\circ} \mathrm{C}$.

\subsection{Thickening Time}

The thickening time tests of slurries were performed in an HTHP consistometer. Measurements were carried out at a temperature of $40{ }^{\circ} \mathrm{C}$ and a pressure of $10 \mathrm{MPa}$. The time necessary to reach the test temperature and pressure is $20 \mathrm{~min}$. This is the time needed to pump this type of slurry to a wellbore. Tests were carried out under dynamic conditions and the slurry continuously moved, which corresponds with pumping it to the wellbore. As the data presented in Table 2 shows the lightweight slurry no. 1 used so far has the thickening start $(30 \mathrm{Bc})$ after 04:20 hours, and the thickening end (100 Bc) after 04:50 hours. As Table 2 shows, the second slurry, due to the existence of a larger amount of microspheres, setting accelerator, and a smaller amount of water, has a shorter time to the thickening start $3 \mathrm{~h}$. The value of $100 \mathrm{Bc}$ in this slurry is $05: 18$ hours. The ultra-lightweight slurry no. 3 has the thickening start after 03:40 hours, and the thickening end (100 Bc) 04:10 hours. Despite a large difference in $\mathrm{w} / \mathrm{c}$ values and a significant share of microspheres in this slurry it has very good properties, due to which it features also anti-migration action.

\subsection{Sedimentation Stability of Liquid Cement Slurry}

As the data in Table 2 shows, the lightweight slurry no. 1 with addition of $15 \%$ of microspheres is subject to small segregation. The density of slurry in the top part of the column is $1.24 \mathrm{~g} / \mathrm{cm}^{3}$, in the central part $1.44 \mathrm{~g} / \mathrm{cm}^{3}$, and in the bottom part $1.46 \mathrm{~g} / \mathrm{cm}^{3}$. The segregation of lightweight slurry no. 2 is much stronger and during the measurement it has a density ranging from $1.15 \mathrm{~g} / \mathrm{cm}^{3}$ in the top part of the column to $1.30 \mathrm{~g} / \mathrm{cm}^{3}$ in the bottom part. Such a result confirms that the microsphere is floating in the top part and the heavy cement fractions sediment in the bottom part of the column. Instead, the new ultra-lightweight slurry is stable in terms of sedimentation and features a density of $1.14 \mathrm{~g} / \mathrm{cm}^{3}$ in all parts of the column. Such behavior is caused by the application of $2.5 \%$ of powder perlite, showing strong water absorption properties. Regardless, a high w/c ratio the slurry is stable. In addition, the presence of fine-grained fillers and the setting accelerator cause prevention against fractions of various weights moving in the slurry. 


\subsection{Compressive Strength (Ultrasonic Cement Analyzer-UCA)}

Ultrasonic cement analyzer (UCA) tests were carried out under static conditions, which is opposite to dynamic tests performed in a consistometer. In the UCA the slurry is not mixed, which corresponds to mechanical strength building after placing the slurry in a well. The slurry was placed in an autoclave chamber and heated up to $40{ }^{\circ} \mathrm{C}$ for $20 \mathrm{~min}$. At the same time (for $20 \mathrm{~min}$ ) the pressure in the autoclave increases to $10 \mathrm{MPa}$. During the cement slurry setting the damping of acoustic wave, passing through the setting cement, was measured. Based on that the mechanical strength building during the cement slurry hydration was determined.

Table 4 shows that the lightweight slurry with $15 \%$ addition of microspheres has the highest compression strength after 2 days of hydration, equal to $5.3 \mathrm{MPa}$. This value grows to $8.8 \mathrm{MPa}$ after 28 days of hydration, which is shown in Figure 10. The measurement error of mechanical parameters is within the error range of the measuring device and amounts to $2 \%$. The second lightweight slurry, containing $40 \%$ of microspheres, features the lowest strength. After 2 days of hydration the strength is $4.9 \mathrm{MPa}$, which then increases to $8.5 \mathrm{MPa}$ after 28 days which is shown in Figure 10. Instead, the new ultra-lightweight slurry, despite a significant amount of $60 \%$ of microspheres, features the highest compression strength values. The sample of hardened slurry after 2 days of hydration features a strength of 5.0 MPa and this value grows to $13.8 \mathrm{MPa}$ after 28 days of hydration, which is shown in Figure 10. Therefore, high values of strength in the ultra-lightweight slurry result from the application of fine-grained fillers. A total of $5 \%$ of micro-cement, $5 \%$ of microsilica, and $2.5 \%$ of filter perlite were used. In addition, the application of $4 \%$ of setting accelerator contributes to the increase in strength, despite a big w/c. The admixture of micro-cement and microsilica in the new cement slurry no. 3 strengthens the hydration process, caulks the matrix of the cement sheath, which makes the mechanical parameters of the cement sheath much higher. In contrast, $2.5 \%$ of filter perlite by water absorption increases the viscosity of the slurry. This allows to improve the homogeneity of the cement slurry in liquid state and gives a homogeneous structure after the slurry is set. In addition, filter perlite reduces the slurry density and this is synergistic with the reduction of the slurry density by the addition of microspheres. Filter perlite in slurry no. 3 makes it possible to reduce the amount of bentonite that is used to counteract sedimentation. This is a good performance of perlite, because too much bentonite reduces the mechanical strength of the cement sheath.

Table 4. Parameters of samples of hardened cement slurry.

\begin{tabular}{|c|c|c|c|c|c|c|c|c|c|c|}
\hline \multirow{3}{*}{ Composition No. } & \multicolumn{4}{|c|}{$\begin{array}{c}\text { Compressive Strength } \\
(\mathrm{MPa})\end{array}$} & \multicolumn{4}{|c|}{$\begin{array}{l}\text { Adhesion to Steel } \\
\text { (MPa) }\end{array}$} & \multirow{3}{*}{$\begin{array}{c}\text { Gas Permeability } \\
(\mathrm{mD}) \\
7 \\
7\end{array}$} & \multirow{3}{*}{$\begin{array}{c}\begin{array}{c}\text { Porosity } \\
(\%)\end{array} \\
7\end{array}$} \\
\hline & \multicolumn{8}{|c|}{ After Hydration (days) } & & \\
\hline & 2 & 7 & 14 & 28 & 2 & 7 & 14 & 28 & & \\
\hline 1 & 5.3 & 7.3 & 7.8 & 8.8 & 2.0 & 2.4 & 2.6 & 2.8 & 0.045 & 47.75 \\
\hline 2 & 4.9 & 6.9 & 7.8 & 8.5 & 1.7 & 2.3 & 2.5 & 2.7 & 0.048 & 49.64 \\
\hline 3 & 5.0 & 8.0 & 10.4 & 13.8 & 0.9 & 1.3 & 1.7 & 2.4 & 0.049 & 48.88 \\
\hline
\end{tabular}




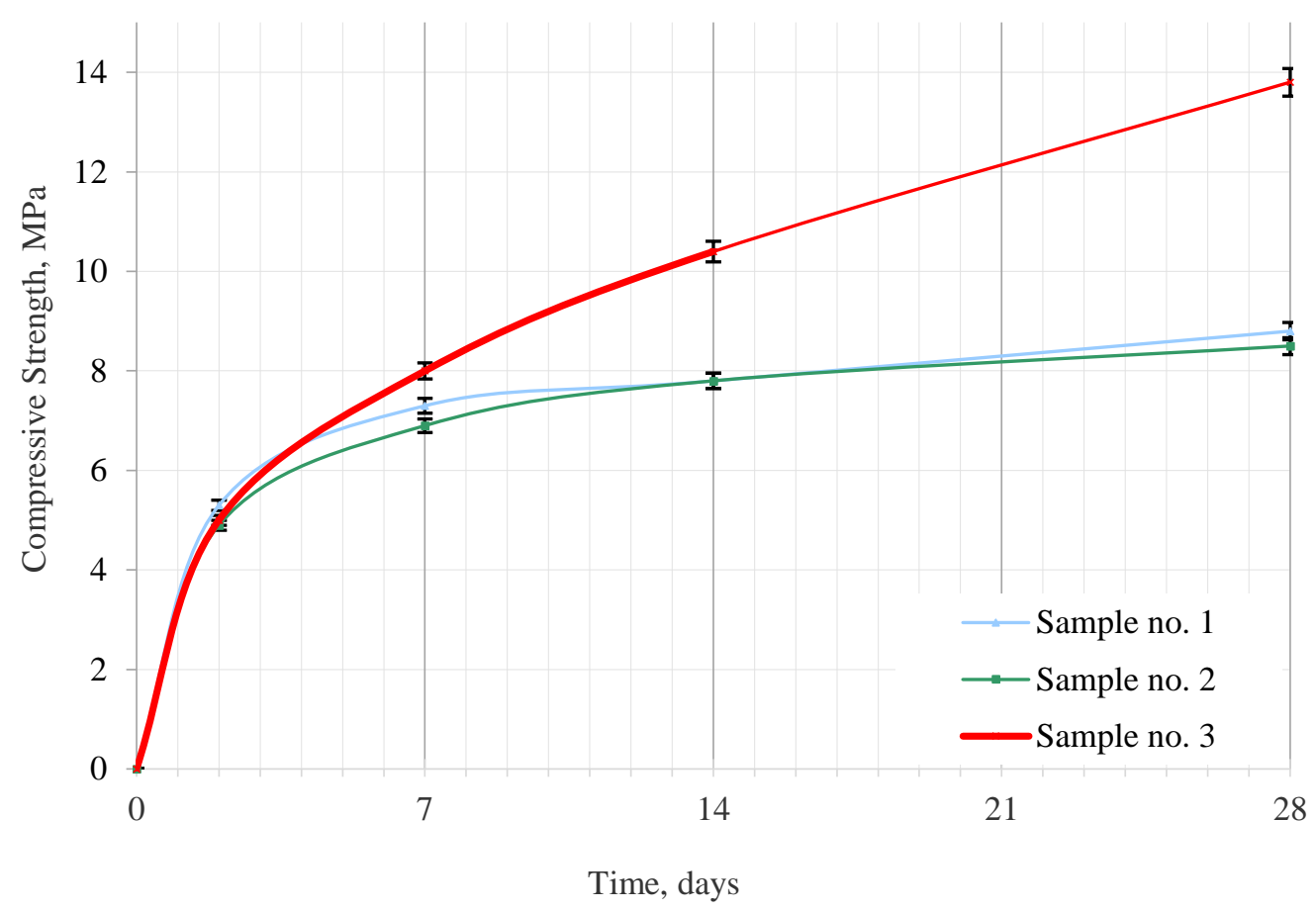

Figure 10. The compressive strength increase curves of the samples $1-3$ at $40{ }^{\circ} \mathrm{C}$.

\subsection{Adhesion to Steel Pipes}

After the required time samples were taken out from the autoclave and after cooling down the adhesion to steel was measured. Table 4 shows that lightweight slurry no. 1 features the highest values of adhesion to steel. The adhesion for this sample ranges between $2 \mathrm{MPa}$ after 2 days of hydration and 2.8 MPa after 28 days of hydration. Lightweight slurry no. 2 has the lowest adhesion, equal to from 1.7 MPa after 2 days to $2.7 \mathrm{MPa}$ after 28 days. While the ultra-lightweight slurry, marked no. 3, features adhesion to steel from 1.3 MPa after 2 days to $2.4 \mathrm{MPa}$ after 28 days. In this case a proportional reduction of adhesion with increasing addition of microspheres is visible. Based on that it was found that the percentage share of microspheres results in decreased adhesion of hardened slurry to steel.

\subsection{Gas Permeability}

Relative gas permeability was measured by means of a cement permeameter. After the slurry preparation it was poured to a mold and placed in an autoclave. For the test needs the conditions set in the autoclave were a temperature of $40^{\circ} \mathrm{C}$ and a pressure of $10 \mathrm{MPa}$. Then, after the required hydration time, the gas permeability was measured. Table 4 shows that the permeability of lightweight slurry no. 1 sample is $0.045 \mathrm{mD}$. Sample no. 2 features the gas permeability of $0.048 \mathrm{mD}$, while the sample of ultra-lightweight slurry $0.049 \mathrm{mD}$. The tests show that permeability grows with the increasing share of microspheres in the slurry. The presence of latex in slurry no. 2 and the reduction of water amount result in a small increase in permeability as compared with sample no. 1. Instead, despite a large amount of water and $60 \%$ of microspheres in slurry no. 3 its permeability is almost comparable with slurry no. 2. Such a small permeability increase in ultra-lightweight slurry no. 3 results from the sealing of cement sheath matrix by means of materials filling empty spaces.

\subsection{Porosity}

The porosity was tested by means of a mercury porosimeter. Samples, after hydration time of 7 days, were placed in the porosimeter and the measurement was performed automatically. Table 4 shows that the sample of slurry with the smallest amount of microspheres, despite a large amount of water, features low porosity of $47.75 \%$. The measurement error of mechanical parameters is within 
the error range of the measuring device and amounts to $1 \%$. The sample of slurry no. 2, despite a smaller amount of mixing water, features a higher value of porosity, equal to $49.64 \%$. Such a value is related to the presence of $40 \%$ of microspheres addition. While, the sample of ultra-lightweight slurry containing $60 \%$ of microspheres and the largest amount of mixing water features porosity of $48.88 \%$, only slightly higher than that of sample no. 1 . This is a lower value than in sample no. 2, containing $40 \%$ of microspheres. Such a small increase in porosity results from the application of fine-grained fillers in the form of micro-cement, microsilica, and filter perlite. In addition, latex fills intergranular spaces, having an additional impact on the cement sheath matrix sealing.

\subsection{Non-Homogeneity of the Cement Sheath Microstructure (Hardened Cement Slurry)}

The non-homogeneity was tested based on the analysis of porosity results. From a cylinder, 1 $\mathrm{m}$ high, containing the set slurry, porosity was measured from the top, central, and bottom parts. The uniformity of the structure was determined based on the obtained results. Figure 11 shows that the sample of slurry no. 1 features porosity of $48.81 \%$ in the top part, $47.75 \%$ in the central part, and $46.2 \%$ in the bottom part of the cylinder. Such results confirmed segregation of the liquid slurry, which resulted in creation of non-homogeneity structure after the slurry setting. Sample no. 2 features even higher porosity values, but also larger dispersion of values between top and bottom parts. In the top part sample no. 2 features porosity of $52.55 \%$, in the central part $49.64 \%$, and at the cylinder bottom the hardened slurry porosity is $47.15 \%$. In turn, porosity results for the sample of ultra-lightweight slurry shown in Figure 11 present minimum differences in the porosity values. Porosity ranges from $48.94 \%$ in the top part to $48.8 \%$ in the bottom part. Such values prove the uniform structure of the tested sample and confirm the sedimentation stability of the liquid slurry. The cement sheath formed from such a slurry in a wellbore should also feature a uniform structure.

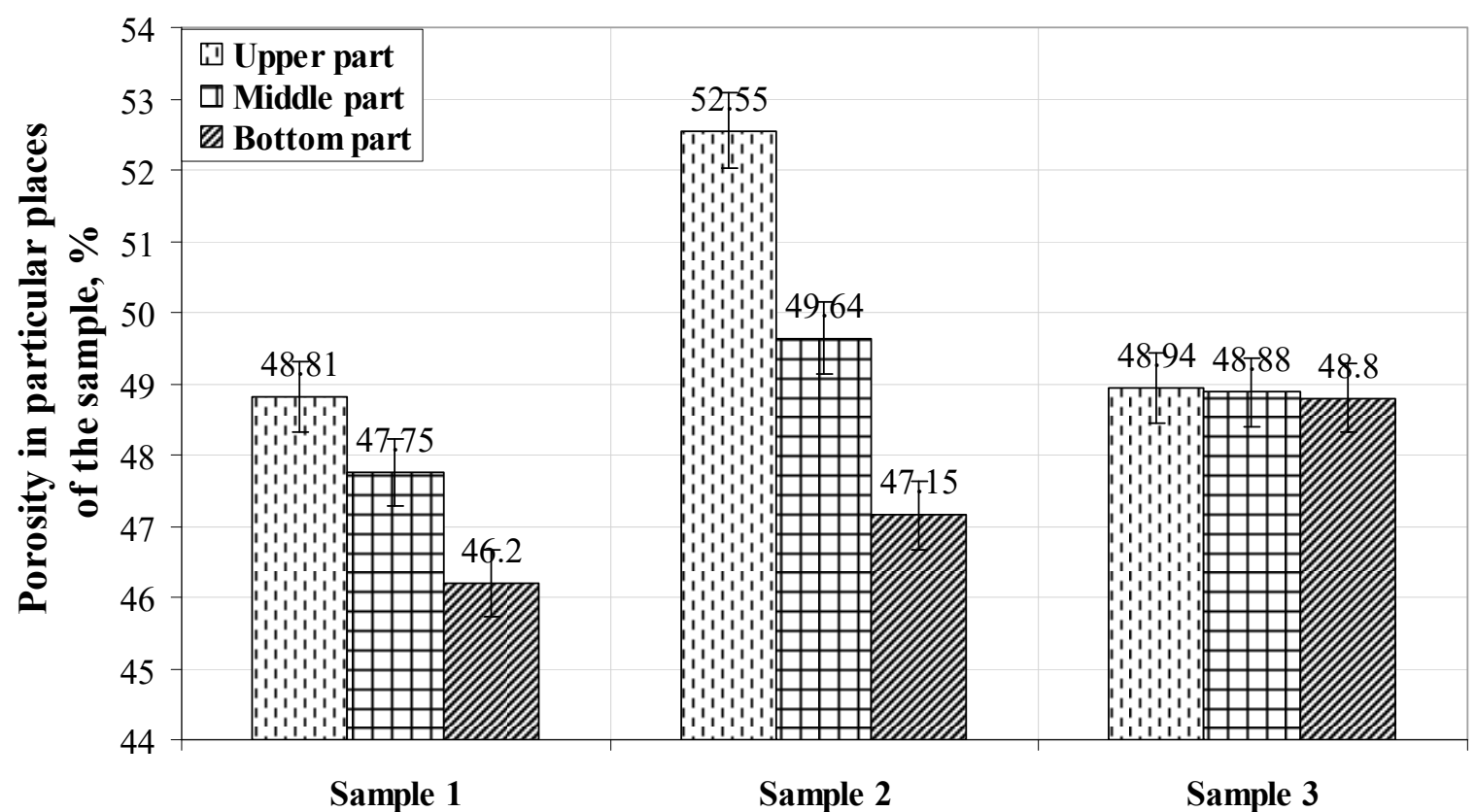

Figure 11. Values of hardened cement slurry porosity at selected points of a cylinder $1 \mathrm{~m}$ high.

\section{Discussion}

Summing up the research results, it was found that the ultra-lightweight cement slurry no. 3 has the best sedimentation stability of those tested. A total of $1.14 \mathrm{~g} / \mathrm{cm}^{3}$ at all measuring points (Table 2). Such values were obtained despite $60 \%$ of aluminosilicate microspheres and a large amount of water. Helpful in improving sedimentation stability is the use of filter perlite (Table 1). A good value of the fresh cement slurry stability results in a homogeneous microstructure of the hardened cement 
slurry. The sample has a porosity of $48.94 \%-48.8 \%$ (Figure 11 ). The remaining samples have a larger spread of values. Despite the large amount of water in the ultra-lightweight cement slurry no. 3 , it has filtration comparable to slurry no. 1, which has less water and cenospheres (Table 2). This effect is caused by the presence of $5 \%$ latex. In addition, latex caulks the microstructure and porosity of the hardened cement slurry of sample no. 3 is lower than sample no. 2. A large amount of water in the cement slurry is necessary with a large amount of microspheres. Additionally, this is needed to obtain rheological parameters at which the cement slurry can be pressed into the borehole. However, water and microspheres reduce the mechanical parameters. This is evident in cement slurries no. 1 and no. 2, where strength decreases in proportion to the amount of microspheres. In the ultra-lightweight cement slurry no. 3, much higher strength values were obtained by introducing $5 \%$ microsilica. In addition, ultra-lightweight cement slurry no. 3 has the required rheological parameters necessary for pressing the slurry into the borehole due to the appropriate selection of means.

\section{Conclusions}

1. Due to the demand for slurries with a much lower density than lightweight slurries and pursuing improvement in wellbore stability a new recipe of ultra-lightweight slurry was developed at the Oil and Gas Institute-National Research Institute. Composition no. 3 is a slurry of density much lower than standard lightweight slurries. Large amounts of water and lightweight fillers are used at designing such slurry. However, such an action results in strong segregation of particles of various densities present in the slurry. The above causes heavier grains to fall to the wellbore bottom and e.g., microspheres float in the top part of the wellbore. Free water in the central part of the wellbore causes destabilization of the wall and drilling complications, costly to remove. It happens that lightweight slurries used now do not feature appropriate sedimentation stability. While, the introduction of an additional portion of microspheres is a factor that intensifies segregation. The ultra-lightweight slurry presented in the paper is not subject to segregation and features a homogeneous structure both in the liquid state and after setting.

2. The density of the newly developed ultra-lightweight slurry is $1.14 \mathrm{~g} / \mathrm{cm}^{3}$. Such a value was obtained due to introduction of $60 \%$ of microspheres to the recipe and by application of a large amount of water, $\mathrm{w} / \mathrm{c}=1.1$.

3. Filtration of the newly developed ultra-lightweight slurry, despite a significant amount of mixing water, is lower than filtration of slurry no. 1, which contains only $15 \%$ of microspheres. Such an effect was obtained by the introduction of fine-grained fillers and a small amount of latex. Ultra-lightweight slurry no. 3 features also the thickening times required for specific geological conditions and it is a ready recipe for sealing wellbores of poor wellbore stability.

4. The new formula of ultra-lightweight slurry features higher values of mechanical parameters than lightweight slurries (no. 1,2) presented in the paper (which as a rule should feature a higher strength). Such an effect is caused by the mixture of micro-cement, microsilica, and filter perlite, present in the recipe. An appropriate quantitative ratio of those microfillers translates into obtaining higher strength values for the ultra-lightweight slurry than for lightweight slurry.

5. The designed ultra-lightweight slurry, because of very low density, protects the wall of a wellbore of poor stability. In addition, the lack of segregation and a short thickening time contribute to limited migration of gas. The obtained parameters of the ultra-lightweight slurry can contribute to improvement in the quality of cementation condition and prevent origination of costly drilling complications.

Funding: The work was financially supported by Ministry of Science and Higher Education Warsaw (Internal order Oil and Gas Institute-National Research Institute Project No. 0024/KW/20).

Acknowledgments: The author thanks the anonymous reviewers for their constructive comments and the editor for handling the paper.

Conflicts of Interest: The author declares no conflict of interest. 


\section{Nomenclature}

Symbol Explanation

CBL the cement bond logging documents the evaluation of the integrity of cement work performed on an oil well

$\mathrm{pH} \quad$ in chemistry, is a scale used to specify how acidic or basic a water-based solution is the specific surface area is a property of solids defined as the total surface area of a material per unit of mass, (with units of $\mathrm{m}^{2} / \mathrm{kg}$ or $\mathrm{m}^{2} / \mathrm{g}$ ) or solid or bulk volume (units of $\mathrm{m}^{2} / \mathrm{m}^{3}$ or m $\mathrm{m}^{-1}$ ). It is

BET determined by adsorption isotherm analysis. The test is carried out using a BET isotherm (isothermal Brunauer-Emmett-Teller), which is a particular form of a linear equation

$\mathrm{Bc}$ the pumpability or consistency of cement slurry, measured in Bearden units of consistency (Bc), a dimensionless quantity with no direct conversion factor to more common units of viscosity

UCA Ultrasonic Cement Analyzer.

HTHP High Temperature High Pressure

w/c water-cement ratio-expresses the amount of water per cement unit

Css the liquid is described by Casson's rheological model

HB the liquid is described by the Herschel-Bulkley rheological model

$\mathrm{p}$ force of pressure causing a break of hardened cement slurry connection with the steel pipe $(\mathrm{kN})$ contact surface of the rock sample with the cement stone $(\mathrm{m})$ permeability $(\mathrm{mD})$

K

$P_{0} \quad$ output pressure (atm) (atmospheric pressure)

$P_{1} \quad$ input pressure (atm)

$Q \quad$ flow rate of the medium (liquid) (cc/s)

$\mu \quad$ viscosity $(\mathrm{cP})$ (nitrogen viscosity $=0.1756 \mathrm{cP}$ under ambient conditions)

$L \quad$ length of sample $(\mathrm{cm})$

A area of sample cross-section $\left(\mathrm{cm}^{2}\right)$

\section{References}

1. Blanco, F.; García, P.; Mateos, P.; Ayala, J. Characteristics and properties of lightweight concrete manufactured with cenospheres. Cem. Concr. Res. 2000, 30, 1715-1722. [CrossRef]

2. Kremieniewski, M. Lekkie zaczyny cementowe do uszczelniania technicznych kolumn rur okładzinowych. Nafta-Gaz 2010, 66, 477-480.

3. Nelson, E.B. Well Cementing; Schlumberger Educational Service: Houston, TX, USA, 1990.

4. Liu, X.; Nair, S.; Aughenbaugh, K.; Van Oort, E. Mud-to-cement conversion of nonaqueous drilling fluids using alkali-activated fly ash. J. Pet. Sci. Eng. 2019, 182, 106242. [CrossRef]

5. Kremieniewski, M. Receptury zaczynów do uszczelniania kolumn rur posadowionych w otworach wierconych w skałach chłonnych. Nafta-Gaz 2019, 75, 451-457. [CrossRef]

6. Chung, S.-Y.; Abd Elrahman, M.; Stephan, D.; Kamm, P.H. The influence of different concrete additions on the properties of lightweight concrete evaluated using experimental and numerical approaches. Constr. Build. Mater. 2018, 189, 314-322. [CrossRef]

7. Brown, D.L.; Ferg, T.E. The Use of Lightweight Cement Slurries and Downhole Chokes on Air-Drilled Wells. SPE Drill. Complet. 2005, 20, 123-132. [CrossRef]

8. Formica, J.J.; Davis, R.J. Lightweight Cement, Ultrasonic Cement Evaluation, and Cased-Hole Dynamics Formation Pressure Tester Combine to Enhance Infill-Drilling Opportunities in Shallow Marine Shelf Deposits, Kern County, California. In Proceedings of the SPE Western Regional Meeting, Irvine, CA, USA, 30 March-1 April 2005. [CrossRef]

9. Kremieniewski, M.; Stryczek, S. Zastosowanie cementu wysokoglinowego do sporządzania zaczynów uszczelniających w technologiach wiertniczych. Cem. Wapno Beton 2019, 22, 215-226. [CrossRef]

10. Jordan, A.; Pernites, R.; Albrighton, L.; Services, B.J. Low-Density, Lightweight Cement Tested as Alternative to Reduce lost Circulation, Achieve Desired Top of Cement in Long Horizontal Wells. Drill. Contract. 2018, 62, 64. Available online: https://www.drillingcontractor.org/low-density-lightweight-cement-tested-as-alternativeto-reduce-lost-circulation-achieve-desired-top-of-cement-in-long-horizontal-wells-48355 (accessed on 1 March 2020). 
11. Curtis, J.A.; Dajani, M.R. Guidelines for Appropriate Application of Non-Foamed Ultralightweight Cement Slurries. In Proceedings of the SPE/IADC Drilling Conference and Exhibition, Amsterdam, The Netherlands, 17-19 March 2009. [CrossRef]

12. Du, H. Properties of ultra-lightweight cement composites with nano-silica. Constr. Build. Mater. 2019, 199, 696-704. [CrossRef]

13. Kulakofsky, D.S.; Paredes, J.L.; Rivera, J.A. Ultralightweight Cementing Technology Sets World's Record for Liner Cementing With a $5.4 \mathrm{lb} / \mathrm{gal}$ Slurry Density. In Proceedings of the IADC/SPE Drilling Conference, Miami, FL, USA, 21-23 February 2006. [CrossRef]

14. Crook, R.; Heathman, J. Predicting potential gas-flow rates to help determine the best cementing practices. Drill. Contr. 1998, 11, 40-43.

15. Abd Elrahman, M.; Chung, S.Y.; Sikora, P.; Rucinska, T.; Stephan, D. Influence of nanosilica on mechanical properties, sorptivity, and microstructure of lightweight concrete. Materials 2019, 12, 3078. [CrossRef] [PubMed]

16. Al-Yami, A.S.; Nasr-El-Din, H.A.; Al-Humaidi, A.S.; Al-Saleh, S.H.; Al-Arfaj, M.K. Evaluation and Optimization of Low-Density Cement: Laboratory Studies and Field Application. SPE Drill. Complet. 2010, 25, 70-89. [CrossRef]

17. Leyton-Vergara, M.; Pérez-Fargallo, A.; Pulido-Arcas, J.; Cárdenas-Triviño, G.; Piggot-Navarrete, J. Influence of Granulometry on Thermal and Mechanical Properties of Cement Mortars Containing Expanded Perlite as a Lightweight Aggregate. Materials 2019, 12, 4013. [CrossRef] [PubMed]

18. Huang, X.; Liu, L.; Zhao, X.; Tang, C.; Wang, X. Properties of Phosphorus-Slag-Based Cementitious Pastes for Stabilizing Lead. Materials 2019, 12, 3831. [CrossRef] [PubMed]

19. Kremieniewski, M. Recipe of Lightweight Slurry with High Early Strength of the Resultant Cement Sheath. Energies 2020, 13, 1583. [CrossRef]

20. Kremieniewski, M. Zaczyny do uszczelniania otworów w warunkach niskich wartości gradientów ciśnienia szczelinowania skał oraz do prac rekonstrukcyjnych. Nafta-Gaz 2020, 76, 102-109. [CrossRef]

21. Chung, S.-Y.; Han, T.-S.; Yun, T.S.; Yeom, K.S. Evaluation of the anisotropy of the void distribution and the stiffness of lightweight aggregates using CT imaging. Constr. Build. Mater. 2013, 48, 998-1008. [CrossRef]

22. Pang, X.; Boul, P.J.; Cuello Jimenez, W. Nanosilicas as Accelerators in Oilwell Cementing at Low Temperatures. In Proceedings of the IADC/SPE Drilling Conference and Exhibition, Fort Worth, TX, USA, 4-6 March 2014. [CrossRef]

23. Daou, F.; Piot, B.M. Cement-Slurry Performance and Set-Cement Properties vs. Microsilica Densification. In Proceedings of the IADC/SPE Drilling Conference, Orlando, FL, USA, 4-6 March 2008. [CrossRef]

24. Baltazar-Zamora, M.A.; Bastidas, D.M.; Santiago-Hurtado, G.; Mendoza-Rangel, J.M.; Gaona-Tiburcio, C.; Bastidas, J.M.; Almeraya-Calderón, F. Effect of Silica Fume and Fly Ash Admixtures on the Corrosion Behavior of AISI 304 Embedded in Concrete Exposed in 3.5\% NaCl Solution. Materials 2019, 12, 4007. [CrossRef]

25. Shabbar, R.; Nedwell, P.; Wu, Z. Mechanical properties of lightweight aerated concrete with different aluminum powder content. MATEC Web Conf. 2017, 120, 02010. [CrossRef]

26. Kremieniewski, M. Wpływ perlitu pylistego na własności technologiczne zaczynu cementowego. Nafta-Gaz 2017, 12, 943-952. [CrossRef]

27. Chen, W.; Huang, Z. Experimental Study of the Mechanical Properties and Microstructures of Lightweight Toughness Cement-Based Composites. Materials 2019, 12, 3891. [CrossRef] [PubMed]

28. Khalil, M.; Jan, B.M.; Raman, A.A.A. Rheological and statistical evaluation of nontraditional lightweight completion fluid and its dependence on temperature. J. Pet. Sci. Eng. 2011, 77, 27-33. [CrossRef]

29. Medley, G.H.; Maurer, W.C.; Garkasi, A.Y. Use of Hollow Glass Spheres for Underbalanced Drilling Fluids. In Proceedings of the SPE Annual Technical Conference and Exhibition, Dallas, TX, USA, 22-25 October 1995. [CrossRef]

30. Wang, G.; Cao, C.; Pu, X.; Zhao, Z. Experimental investigation on plugging behavior of granular lost circulation materials in fractured thief zone. Part. Sci. Technol. 2016, 34, 392-396. [CrossRef]

31. Kremieniewski, M.; Kędzierski, M. Badanie frakcjonowania lekkich materiałów obniżających gęstość jako wstępnego parametru podczas projektowania receptury zaczynu lekkiego. Nafta-Gaz 2019, 12, 35-42. [CrossRef] 
32. Kremieniewski, M.; Stryczek, S.; Wiśniowski, R.; Gonet, A. Zmniejszanie porowatości stwardniałych zaczynów wiertniczych poprzez wprowadzenie dodatków drobnoziarnistych. Cem. Wapno Beton 2016, 21, 325-335.

33. Garbalinska, H.; Strzałkowski, J. Thermal and strength properties of lightweight concretes with variable porosity structures. J. Mater. Civ. Eng. 2018, 28, 567-575. [CrossRef]

34. Zhao, S.; Sun, W. Nano-mechanical behavior of a green ultra-high performance concrete. Constr. Build. Mater. 2014, 63, 150-160. [CrossRef]

35. Mbessa, M.; Péra, J. Durability of high-strength concrete in ammonium sulfate solution. Cem. Concr. Res. 2001, 31, 1227-1231. [CrossRef]

36. Sadowski, Ł.; Popek, M.; Czarnecki, S.; Mathia, T.G. Morphogenesis in solidification phases of lightweight concrete surface at early ages. Constr. Build. Mater. 2017, 148, 96-103. [CrossRef]

37. Bonett, A.; Pafitis, D. Getting to the root of gas migration. Oilfield Rev. 1996, 8, 36-49.

38. Kremieniewski, M. Wpływ drobnoziarnistej krzemionki na parametr czasu oczekiwania na cement - WOC. Nafta-Gaz 2019, 75, 683-690. [CrossRef]

39. Carathers, K.; Crook, R. Surface Pipe Cement Gives High Early Strength with New Cement Additive; South-Wester Petroleum Short Course: Lubbock, TX, USA, 1987; pp. 12-19.

40. Fantilli, A.P.; Paternesi Meloni, L.; Nishiwaki, T.; Igarashi, G. Tailoring Confining Jacket for Concrete Column Using Ultra High Performance-Fiber Reinforced Cementitious Composites (UHP-FRCC) with High Volume Fly Ash (HVFA). Materials 2019, 12, 4010. [CrossRef] [PubMed]

41. Aguilar, A.S.; Melo, J.P.; Olivares, F.H. Microstructural analysis of aerated cement pastes with fly ash, metakaolin and Sepiolite additions. Constr. Build. Mater. 2013, 47, 282-292. [CrossRef]

42. Huang, Z.; Padmaja, K.; Li, S.; Richard Liew, J.Y. Mechanical properties and microstructure of ultra-lightweight cement composites with fly ash cenospheres after exposure to high temperatures. Constr. Build. Mater. 2018, 164, 760-774. [CrossRef]

43. Bellotto, M. Cement paste prior to setting: A rheological approach. Cem. Concr. Res. 2013, 52, 161-168. [CrossRef]

44. Kim, M.; Kang, S.-H.; Hong, S.-G.; Moon, J. Influence of Effective Water-to-Cement Ratios on Internal Damage and Salt Scaling of Concrete with Superabsorbent Polymer. Materials 2019, 12, 3863. [CrossRef] [PubMed]

45. Ramamurthy, K.; Narayanan, N. Factors influencing the density and compressive strength of aerated concrete. Mag. Concr. Res. 2000, 52, 163-168. [CrossRef]

46. Thiercelin, M.J.; Dargaud, B.; Baret, J.F.; Rodriquez, W.J. Cement Design Based on Cement Mechanical Response. SPE Drill. Complet. 1998, 13, 266-273. [CrossRef]

47. Kim, J.; Honda, D.; Choi, H.; Hama, Y. Investigation of the Relationship between Compressive Strength and Hydrate Formation Behavior of Low-Temperature Cured Cement upon Addition of a Nitrite-Based Accelerator. Materials 2019, 12, 3936. [CrossRef]

48. Bogas, J.A.; Brito, J.; Figueiredo, J.M. Mechanical characterization of concrete produced with recycled lightweight expanded clay aggregate concrete. J. Clean. Prod. 2015, 89, 187-195. [CrossRef]

49. Abbas, G.; Irawan, S.; Kumar, S.; Memon, R.K.; Khalwar, S.A. Characteristics of Oil Well Cement Slurry using Hydroxypropylmethylcellulose. J. Appl. Sci. 2014, 14, 1154-1160. [CrossRef]

50. Colombo, A.; Geiker, M.; Justnes, H. The effect of calcium lignosulfonate on ettringite formation in cement paste. Cem. Concr. Res. 2018, 107, 188-205. [CrossRef]

51. Collepardi, M.; Marchese, B. Morphology and Surface Properties of Hydrated Tricalcium Silicate Pastes. Cem. Concr. Res. 1972, 2, 57-65. [CrossRef]

52. Tao, C.; Kutchko, B.G.; Rosenbaum, E.; Wu, W.-T.; Massoudi, M. Steady Flow of a Cement Slurry. Energies 2019, 12, 2604. [CrossRef]

53. PN-EN ISO 10426-2. Petroleum and Natural Gas Industries. Cements and Materials for Well Cementing. Part 2: Testing of Well Cements; ISO: Geneva, Switzerland, 2003.

54. Stryczek, S.; Wiśniowski, R.; Gonet, A.; Ferens, W. Parametry reologiczne świeżych zaczynów uszczelniających w zależności od czasu ich sporządzania. Wiert. Naft. Gaz 2009, 26, 369-382.

55. Wiśniowski, R.; Skrzypaszek, K. Komputerowe wspomaganie wyznaczania modelu reologicznego cieczy-Program Flow-fluid Coef. Nowocz. Tech. i Technol. Bezwykopowe 2001, 2-3, 72-77.

56. Wiśniowski, R.; Stryczek, S.; Skrzypaszek, K. Kierunki rozwoju badań nad reologia płynów wiertniczych. Wiert. Naft. Gaz 2007, 24, 595-607. 
57. Struble, L.; Sun, G.-K. Viscosity of Portland cement paste as a function of concentration. Adv. Cem. Based Mater. 1995, 2, 62-69. [CrossRef]

58. Liu, L.; Fang, Z.; Qi, C.; Zhang, B.; Guo, L.; Song, K.I.-I.L. Numerical study on the pipe flow characteristics of the cemented paste backfill slurry considering hydration effects. Powder Technol. 2019, 343, 454-464. [CrossRef]

59. British Standards Institution. BS EN 196-1:2016 Methods of Testing Cement. Determination of Strength. Available online: https:/www.thenbs.com/PublicationIndex/documents/details?Pub=BSI\&DocID=314246 (accessed on 1 March 2020).

60. PN-EN ISO 1302. Geometrical Product Specifications (GPS)_Indication of Surface Texture in Technical Product Documentation; ISO: Geneva, Switzerland, 2002.

61. Roussel, N. A Theoretical Frame to Study Stability of Fresh Concrete. Mater. Struct. 2006, 39, 81-91. [CrossRef]

62. Zuo, W.; Liu, J.; Tian, Q.; Xu, W.; She, W.; Feng, P.; Miao, C. Optimum design of low-binder Self-Compacting Concrete based on particle packing theories. Constr. Build. Mater. 2018, 163, 938-948. [CrossRef]

(C) 2020 by the author. Licensee MDPI, Basel, Switzerland. This article is an open access article distributed under the terms and conditions of the Creative Commons Attribution (CC BY) license (http://creativecommons.org/licenses/by/4.0/). 